\author{
Abstracta Iranica \\ Abstracta Iranica Revue bibliographique pour le domaine irano-aryen \\ Volume 42-43 | 2021 \\ Comptes rendus des publications de 2019-2020
}

\title{
Farzaneh Hemmasi. Tehrangeles Dreaming: Intimacy and Imagination in Southern California's Iranian Pop Music
}

\section{Laetitia Nanquette}

\section{(2) OpenEdition Journals}

Electronic version

URL: https://journals.openedition.org/abstractairanica/52754

DOI: 10.4000/abstractairanica.52754

ISSN: 1961-960X

Publisher:

CNRS (UMR 7528 Mondes iraniens et indiens), Éditions de l'IFRI

\section{Electronic reference}

Laetitia Nanquette, "Farzaneh Hemmasi. Tehrangeles Dreaming: Intimacy and Imagination in Southern California's Iranian Pop Music", Abstracta Iranica [Online], Volume 42-43| 2021, document 2, Online since 15 April 2021, connection on 13 December 2022. URL: http://journals.openedition.org/ abstractairanica/52754 ; DOI: https://doi.org/10.4000/abstractairanica.52754

This text was automatically generated on 13 December 2022.

All rights reserved 


\title{
Farzaneh Hemmasi. Tehrangeles
} Dreaming: Intimacy and Imagination in Southern California's Iranian Pop Music

\author{
Laetitia Nanquette
}

\section{REFERENCES}

Farzaneh Hemmasi. Tehrangeles Dreaming: Intimacy and Imagination in Southern California's Iranian Pop Music. Durham: Duke University Press, 2020, 264p., 40 illust. ISBN:

978-1-4780-0836-1

1 This book explores the production of pop music in Tehrangeles, a name given to Los Angeles by the Iranian diaspora, through its impact on Iranian identity. This form of pop music has been circulating widely abroad and in Iran for decades, and it is particularly relevant when considering cultural exchanges between Iran and its diaspora. Hemmasi explores how music producers have positioned themselves to reflect on the question of the Iranian nation. The book is particularly interesting when it discusses the impact of Tehrangeles pop on Iranians within, in political, social and moral terms, and how pop offers different ways of being Iranian from those proposed by the Iranian state.

2 The writing is engaging, filled with stories about fieldwork and encounters. Pop music might be seen as superficial by some, but it touches upon many political issues and brings about conflicts that Hemmasi convincingly analyses. 


\section{AUTHORS}

\section{LAETITIA NANQUETTE}

University of New South Wales, Sydney 